\title{
Deuteronomy between Pentateuch and the Deuteronomistic history
}

\author{
John van Seters ${ }^{1}$ \\ Wilfrid Laurier University (Waterloo, Ontario, Canada) \\ Visiting Professor: University of Pretoria
}

\begin{abstract}
The problem of how Deuteronomy relates to the Pentateuch and to the book of Joshua came to the fore with Noth's thesis of a Deuteronomistic History, which was in conflict with the earlier support for a Hexateuch in the Documentary Hypothesis. With the current decline of the Documentary Hypothesis, one approach is to give greater emphasis to Pentateuchal and Hexateuchal redactors, often in place of the $J$ and $P$ sources, which either use Deuteronomy to conclude the Pentateuch or to build a bridge to the Deuteronomistic History. An alternative view, expressed in this paper, rejects the notion of such redactors and sees $J$ and $P$ as later than, and supplementary to, the Deuteronomistic History. To support this view, the article will examine Eckart Otto's Pentateuchal redactor in Deuteronomy 4, at parallel texts in Numbers and Deuteronomy, and at Pentateuchal and Hexateuchal redactors in Deuteronomy 34 and Joshua 24.
\end{abstract}

\section{INTRODUCTION: THE CURRENT STATE OF THE PROBLEM}

The problem of how Deuteronomy relates to the Pentateuch, on the one hand, and to the book of Joshua, on the other, can be seen most clearly in the way in which the issue was posed between Gerhard von Rad, with his support of a Hexateuch, and Martin Noth, with his reconstruction of a Deuteronomistic history

\footnotetext{
${ }^{1}$ This article is based on a paper, presented by Prof Dr John van Seters at the Pro-Pent conference, 30 August - 2 September 2002, University of Pretoria (Hammanskraal Campus). Pro-Pent is a project of the Department of Old Testament Studies, focusing on research on the Pentacheuchal Tradition. Prof Van Seters was the guest of Prof Dr A P B Breytenbach, Department of Old Testament Studies, Faculty of Theology, University of Pretoria. Financial assistance from the National Research Foundation (NRF) is hereby acknowledge. Opinions expressed in this research, or conclusions drawn, are those of the author and not necessarily of the NRF.
} 
from Deuteronomy to 2 Kings and with the Pentateuch being reduced to a Tetrateuch. The notion of a Hexateuch arose out of the Documentary Hypothesis and is based upon the observation that the accounts of the Pentateuchal sources $\mathrm{J}, \mathrm{E}, \mathrm{D}$, and $\mathrm{P}$, are not complete without the narration of the conquest of Joshua. This is the position that Von Rad defended, and he insisted, against Gunkel and others, that this basic compositional structure from creation to the conquest of the land was the work of a historian and author, the Yahwist, and not the result of an accidental traditio-historical process. Noth's construction of a similar history, the Deuteronomistic History (DH) from Deuteronomy to 2 Kings, however, put advocates of the Hexateuch like Von Rad on the defensive. Noth solved the problem of the conflicting histories by reducing the Pentateuch (i e, the Tetrateuch) to blocks of tradition based on themes that came together through a nebulous traditio-historical process, which reduced the author, the Yahwist to insignificance. The subsequent connections between the Tetrateuch and the $\mathrm{DH}$ were all explained by endless Deuteronomistic and Priestly redactors, thereby creating a de facto redactional Hexateuch (Van Seters, forthcoming).

Revisions to Pentateuchal criticism in the seventies, which called into question the classical Documentary Hypothesis, have led to two basic options concerning the problem of the Hexateuch. One approach is to continue Noth's notion of tradition blocks (but without sources $\mathrm{J}$ and $\mathrm{E}$ ) and his use of redactors who put the blocks together. This approach is primarily concerned with the interconnections of the themes of the Pentateuch rather than sources but may also be extended to include the theme of Joshua's conquest as a quasiHexateuch. This is the approach used by Rolf Rendtorff (1977) and followed in modified form by Erhard Blum (1984, 1990), Konrad Schmid (1999), Thomas Römer (2000) and others. The other option is to follow the direction of Von Rad in asserting the primacy of authors, such as the Yahwist, but to construe the relationship of such Pentateuchal authors to the $\mathrm{DH}$ as that of supplementation (Van Seters 1999:58-86). Thus J (non-P) and $P$ in the Tetrateuch are later than Deuteronomy and the $\mathrm{DH}$, and represent an expansion of that corpus into the more remote past. These two approaches are completely incompatible. 
The problem with the Documentary Hypothesis is not the multiplicity of sources or authors in the Pentateuch, for which there is abundant evidence. The problem is with the whole notion of redactors as a literary explanation for their combination. This is the fundamental fallacy of $19^{\text {th }}$ century literary criticism that, after two centuries, is still perpetuated in redaction criticism in biblical studies today. Most of the criticism directed against the Documentary Hypothesis by Rendtorff and others is, in my view, completely misguided and has done more damage than the older views of Pentateuchal studies. That is also my fundamental disagreement with Eckart Otto and his understanding of the relationship of Deuteronomy to the Pentateuch. This may best be illustrated by a particular example taken from a recent critique of my work by Otto (2002:130-34).

\section{THE RELATIONSHIP OF P TO DEUTERONOMY}

In his objection to my supplementary approach to the relationship of $\mathrm{P}$ to Deuteronomy, Otto raises a question concerning the lack of Priestly additions to Deuteronomy, which he considers a problem for my view. This, of course, is the argument used by Israeli and Jewish scholars for any late dating of $P$ and who therefore want to date $\mathrm{P}$ earlier than $\mathrm{D}$. Otto now deems it convenient to use the same argument for his own purposes to support his redaction criticism of Deuteronomy. In my view, the additions of both $\mathrm{J}$ and $\mathrm{P}$ to $\mathrm{D}$ and $\mathrm{DH}$ were minimal for obvious reasons. They had the chance to say what they wanted to say in Genesis to Numbers and there was little left to add, except to comment on the last days of Moses' life. P did make a big addition to Joshua, and that caused Noth much difficulty, so he had to delete Numbers 26 and 27:1-11, parts of 32, and 33-36 from $P$ and assign it to a redactor. Once that expedient was introduced there was no stopping the invention of multiple redactors.

Against my view that Exodus 19-20 depends upon Deuteronomy 4-5, Otto takes over the view of Fishbane that Deuteronomy 4 is a midrashic interpretation of Genesis 1 (Fishbane 1985: 321-22). For Fishbane D is later than P, and virtually the whole of $D$ is an inner-biblical interpretation of both the Covenant Code and P. But is Deuteronomy 4:16b-19a a "literal quotation" of Genesis 1:14- 
27 (Otto 2002:132) or an "explicit aggadic adaptation" (Fishbane 1985:321)? Certainly not! The language is quite different. The series "all the animals that are on the earth", "all winged birds that fly in the sky", "all reptiles that creep (רמש) on the ground", "all fish that are in the sea"(v. 17), is very similar to the series used by $\mathrm{J}$ in the flood story (Gen 6:7), except that the fish are excluded for obvious reasons. Otto also mentions the P phraseology in 4:25, using ילד in the Hiph ${ }^{c} i l$ and ברא 4:32. But why must these be evidence of $P$ use? ילד in the Hiph also used in a very similar way in Deuteronomy 28:41, but this text, according to Otto is seventh century D (Otto 1999:64-69). בראי is also used by J in Genesis 6:7 in a very similar manner. Before we invoke yet another redactor to solve this problem let me hasten to mention that ברא occurs several times in DeuteroIsaiah, J's contemporary, according to my view. Now Fishbane makes much of this use of ברא and sees Deutero-Isaiah as also commenting on Genesis 1 (Fishbane 1985:322-26). Does Otto advocate this solution, or would he like to see a post-P redactor in Deutero-Isaiah? My own solution, which is that both $\mathrm{J}$ and Deutero-Isaiah are a little later than, and dependent upon, Deuteronomy 4, is too simple for Otto, but I will stick to it anyway.

\section{COMPARISON BETWEEN PARALLEL TEXTS IN D AND J (NON-P): EARLIER STUDIES}

Deuteronomy presents itself as a recapitulation of events that have taken place prior to the arrival of the Israelites in the plains of Moab under the shadow of Pisgah and opposite Jericho. It is assumed by most biblical readers that the references to prior events have to do with those that are now reflected in the Tetrateuch from the time of the giving of the Decalogue at Sinai/Horeb to the eve of the conquest under Joshua, and many scholars have uncritically followed this same assumption. Already 30 years ago I attempted to show that the account of the conquest of the kingdoms of Sihon and Og in Numbers 21 is not the source for Deuteronomy but the reverse (Van Seters 1972:182-97). In the years that followed I have won some support for this view (Miller 1989:577-99; Schmitt 
1988:26-34; Smelik 1984:61-109). But these conquest narratives of Numbers 21 are not just a later addition to the $\mathrm{J}$ (non $\mathrm{P}$ ) narrative. I have subsequently argued that all of the parallel narratives in Deuteronomy are the sources of those in Exodus-Numbers (Van Seters 1994), starting with the Sinai theophany in Exodus 19-20 and its parallel in Deuteronomy 4-5; the golden calf episode of Exododus 32 with its sources in Deuteronomy 9 and 1 Kings 12; the story of the spies and the aborted invasion from the south in Numbers 13-14 and its counterpart in Deuteronomy 1:19-46; the final trek from Kadesh to the plains of Moab, including the conquest of the eastern territories in Numbers 20-21, and their parallel in Deuteronomy 2-3; the distribution of the eastern regions in Numbers 32 and their parallel in Deuteronomy 3:12-22. In every one of these cases close scrutiny demonstrates that Deuteronomy contains the older version of the episode in question. Furthermore, the clear, tightly crafted sequence of events in Deuteronomy 1-3 has been broken up and interspersed with many other episodes, such as murmuring episodes and the Baalam story by the author of Numbers $(\mathrm{J})$, such that it is hardly conceivable that the so-called Deuteronomist (Dt) could have extracted his narrative from $\mathrm{J}$ and discarded the rest. Any serious discussion of the relationship of Deuteronomy to the Pentateuch must begin with a thorough treatment of these parallel narratives, but with a few exceptions (Rose 1981), this has still been largely neglected. Since I have dealt with this subject at length in previous publications I will not repeat them here. Instead I will focus on the final scene of Moses' death in Deuteronomy 34.

\section{THE FINAL SCENE OF MOSES' DEATH IN D, J AND P: DEUTERONOMY 34}

A recent proposal by Thomas Römer and Marc Brettler argues for a "Hexateuchal redactor" who is presented as competing with a "Pentateuchal redactor"(Römer \& Brettler 2000: 401-19). Key to this discussion is their understanding of Deuteronomy 34 and Joshua 24. In this they follow a suggestion by Erhard Blum who identified Joshua 24 as the work of a Hexateuchal redactor, as distinct from his Pentateuchal "compositions" KD and 
KP (Blum 1990:364-65; 1997:194-206). Blum goes so far as to identify the "Book of the Torah of God" in Joshua 24:26 as a reference to the Hexateuch, a redefinition of the Heilsgeschichte. This seems seriously to stretch the meaning of the phrase, "the Book of the Torah of God," which rather refers back to the preceding covenant with its statutes and ordinances in verse 25. (see the parallel in Josh 8:30-35). Nevertheless, the primary argument for the Hexateuchal redactor, as taken up by Römer and Brettler, is the proposal that Joshua 24 was composed as a concluding statement of the Hexateuch, to create a break with the time of the judges.

To focus clearly on this issue we need also to bracket Judges 1:1-2:5 as an interruption in the continuity of $\mathrm{DH}$. The original history, therefore, went from Joshua 23 to Judges 2:6-10. So Joshua 24 is also an addition, but at an earlier level than Judges 1:1-2:5 because it still maintained this continuity with Judges in verses 28-31. The only serious interruptions, then, are verses 32-33. But verse 33 recounting the death and burial of Eleazar, the high priest, is a priestly addition because for $P$, Eleazar must be viewed as the equal of Joshua and be treated in the same way with a burial site. This leaves only verse 32 , the remark about the final burial of Joseph's bones, as a possible break in the continuity between Joshua and Judges. Its purpose is to make clear a connection back to the patriarchal age. The theme is linked to J's ending to the Joseph story in Genesis 50:24-26 and the transport of Joseph's bones at the time of the exodus in Exodus 13:19. In this last case the mention of Joseph's bones does not seriously interrupt the sequence of events in Exodus 13:18-22 and there is, likewise, no reason to regard Joshua 24:32 as a deliberate attempt to break with what follows and closes the Hexateuch. Furthermore, if Joshua 24 was not intended to be continued in Judges, then why include the remarks in verse 31 , "Israel served Yahweh all the days of Joshua and all the days of the elders who outlived Joshua ...", which has to do with the period following Joshua's death and which is continued in Judges 2:10ff as the original sequence of $\mathrm{DH}$ ? (The rearrangement of the text in Jdg 2:6-9 - a resumptive repetition of Josh 24:28-31 - was necessary to fit Jdg 1:1-2:5 into its present position.) 
The content of Joshua 24 not only points to the past history of the people up to the time of Joshua's death, but it also anticipates the future history of the people. The long dialogue between Joshua and the people about their future commitment to serving Yahweh raises the question: How long would the people remain faithful to Yahweh? Do we have any indications of a connection between this theme in Joshua 24 and what follows in Judges? In Judges 6:7-10 we have a unit that is often characterized as $\mathrm{Dt}$, but an obvious problem with it is that it appears somewhat redundant and intrusive between verses 6 and 11 which is the Dt's account of Gideon's call. Verses 7-10 include some of the same themes of Israel's rescue from Egypt, etcetera, so scholars have described 6:7-10 as "late" Dt. But a close examination reveals the fact that it has vocabulary and themes that are not typical of Dt (see Becker, 1990:144-45). For instance, this would be the only place in Dt where גרש is used to speak of Yahweh "driving out" the prior inhabitants, in contrast to the usual Dt theme of extermination. Yet this reference to "driving out" the prior inhabitants corresponds to the usage in Joshua 24:12 (and other J passages, Ex 23:28-29). There is also the notion about "worshipping the gods of the Amorites in whose land you dwell" (Jdg 6:10). This is not the usual way in Judges-Samuel of expressing the objects of the people's apostasy. The forbidden gods are the Baals and the Ashtoroth of the peoples who live in the neighbouring lands, whereas the Amorites along with their gods have been wiped out in DH! The language in Judges 6:7-10 conforms directly to that of Joshua 24 . The obvious point of this little unit is to link up the Judges period with Joshua's warning about apostasy and their serving "the gods of the Amorites in whose land you dwell." There is no reason to doubt that both texts are by the same hand. Consequently there is no literary basis for a Hexateuch.

Let us now go back to Deuteronomy 34 in which it is claimed by Römer and Brettler that there are two competing endings, one by a Pentateuchal redactor and one by the Hexateuchal redactor. I basically agree with them about the DH version of Moses' death and burial on Mount Pisgah in verses $1 a^{*}, 5-6$, which leaves us with two other levels in the text. The disagreement that I have 
with Römer and Brettler is that they attribute the additions of 34:7-9 to a Hexateuchal redactor and verses $1 b-4^{\star}, 10-12$ to a Pentateuchal redactor. Yet it is not clear to me what objective criteria can be used to make such attributions since the division of texts seems to largely follow the older source attributions to $\mathrm{J}$ and $\mathrm{P}$, which are now converted into redactors. Comparison with the views of Blum on these verses is instructive. While Blum does not offer an analysis of the whole chapter, he does ascribe verses 7-9 to his KP (=P) composition, mainly on the strength of the Priestly connections of verse 9 with Numbers $27: 18-23$, and he ascribes verses 10-12 to his KD (=J) (Blum 1990:76-88, 227). In the latter case he sees a strong interconnection with a "complex bundle of crossreferences" of texts (Ex 33-34; Nm 11-12; Dt 31:14-15, 23) that he ascribes to $K D$. On the one hand, Blum seems to attribute to KD in 34:10-12 the function of marking the conclusion of the "Book of the Torah" of Moses and setting it off from what follows (Blum 1990:88). This would support Römer's and Brettler's notion of a Pentateuchal redactor. On the other hand, the close connection of these verses with the preceding installation of Joshua in Deuteronomy 31:14-15, 23 in KD makes a connection with the following Joshua story (Blum 1990:110-111). The function of both the KP and KD additions, therefore, is to tie these compo-sitions to the $\mathrm{DH}$ as a whole (Blum 1990:227).

An alternate solution to the problem of the Hexateuch is to date the Pentateuchal sources $\mathrm{J}$ and $\mathrm{P}$ as later than $\mathrm{DH}$ and view them as a supplement to it, in which case there is no need for a Hexateuch. Elements of $P$ and non- $P$ $(=\mathrm{J})$ may be found in Deuteronomy and Joshua but they function as cords to tie their early histories into the national tradition (DH). This alternative of a "supplementary hypothesis" that I have long advocated as an answer to the Documentary Hypothesis has not really been addressed by these redactional schemes.

Consequently, my own division of the layers in Deuteronomy 34 is to apply the language criteria of the $\mathrm{J}$ and $\mathrm{P}$ sources to the non-Dt texts (see also Van Seters 1994: 451-56). First let us consider P. Verse 9, the description of Joshua's qualities as Moses' successor, is an obvious $\mathrm{P}$ intrusion that relates back to Numbers 27:18-23. There is also a P gloss in verse 1 , which locates Pisgah more precisely, and another addition in verse 5 "according to the word of Yahweh", 
which creates a link with Deuteronomy 32:48-52 (P). Nothing else is Priestly in Deuteronomy 34. The major addition is by J. The description of the land and the patriarchal promise in $1 \mathrm{~b}-4$, and the rest of the remarks about Moses in verses 78, 10-12 all belong to $\mathrm{J}$ and make a good fit with the non-P materials in the Pentateuch. The age of Moses at his death ( $\vee 7)$, which imitates 31:2, is in J's style similar to that of Joseph in Genesis 50:26, not in P's style. The mourning for Moses is like the mourning for Jacob in Genesis 50:3-4 (J). P imitates this in Numbers 20:29 in the case of Aaron's death but in a different style. The remarks about Moses speaking with the deity face to face corresponds most closely with Exodus 33:11; 34:29-35; Numbers 12:6-8 (all J). These texts are closely related to the "tent of meeting" texts (Ex 33:7-11; Nm 11:16-17, 24-30; 12:1-8) so that it is this same $\mathrm{J}$ source that is responsible for the commissioning of Joshua in Deuteronomy 31:14-15, 23, which makes a link with the conquest of Joshua that follows. The links back to the earlier texts in $\mathrm{J}$ that highlight the role of Joshua are obvious.

Thus, the Dt core in Deuteronomy 34 that makes the transition from the time of Moses to Joshua has been supplemented by J's final recollection of the patriarchal promises in Deuteronomy 34:1b-4, Moses' age at death and the period of mourning in verses 7-8, and an obituary in verses 10-12, to which $\mathrm{P}$ also adds a few glosses. The fact that the author, whom I am calling the Yahwist, chooses to end his life of Moses with a short obituary in Deuteronomy 34:10-12 does not mean that he has created a structural ending to his corpus, a deliberate break with what follows. If one takes the work as a whole, then so much in it points beyond the time of Moses to the conquest that follows. It is the scholarly search for a literary explanation for the Pentateuch in the form of redactors corresponding to a notion about the Torah's canonization in the Persian period (in the form of the present Pentateuch) that is at fault. There is no good evidence for such a canon in the Persian period. And what is even more problematic is searching for a literary explanation for the scholarly construction of the Hexateuch, the brainchild of the Documentary Hypothesis. The Hexateuch is a scholarly fantasy and all the redactors invented to support it are likewise mere fantasies of scholarly ingenuity. 


\section{Works consulted}

Becker, U 1990. Richterzeit und Königtum: Redaktionsgeschichtliche Studien zum Richterbuch. Berlin: W de Gruyter. (BZAW 192.)

Blum, E 1984. Die Komposition der Vätergeschichte. Neukirchen-Vluyn: Neukirchener Verlag. (WMANT 57.)

Blum, E 1990. Studien zur Komposition des Pentateuch. Berlin: W de Gruyter. (BZAW 189.)

Blum, E 1997. Der kompositionelle Knoten am Übergang von Josua zu Richter: Ein Entflechtungsvorschlag, in Vervenne, \& Lust 1997:181-212.

Fishbane, M 1985. Biblical interpretation in ancient Israel. Oxford: Clarendon.

Miller, J M 1989. The Israelite journey through (around) Moab and Moabite toponymy. JBL 108, 577-99.

Otto, E 1999. Das Deuteronomium: Politische Theologie und Rechtsreform in Juda und Assyrien. Berlin: W de Gruyter. (BZAW 284.)

Otto, E 2002. Forschungen zum nachpriesterschriftlichen Pentateuch. ThR 67, 125-155.

Römer, T \& Brettler, M Z 2000. Deuteronomy 34 and the case for a Persian Hexateuch. JBL 119, 401-419.

Rendtorff, R 1977. Das überlieferungsgeschichtliche Problem des Pentateuch. Berlin: W de Gruyter. (BZAW 147.)

Rose, M 1981. Deuteronomist und Jahwist: Untersuchungen zur den Beruhrung-punkten beider Literaturwerke. Zürich: Theologischer Verlag. (ATANT 67.)

Schmid, K 1999. Erzväter und Exodus. Neukirchen-Vluyn: Neu-kirchener Verlag. (WMANT 81.)

Schmitt, H C 1988. Das Hesbonlied Num 21:12a b-30 und die Geschichte der Stadt Hesbon. ZDPV 104, 26-34.

Smelik, K A D 1984. Een vuur gaat uit van Chesbon. Amsterdamse Cahiers 5, 61-109.

Van Seters, J 1972. The conquest of Sihon's kingdom: A literary examination. JBL 91, 182-97.

Van Seters, J 1994. The life of Moses. Louisville: Westminster.

Van Seters, J 1999. The Pentateuch. A social-science commentary. Sheffield: Sheffield Academic Press.

Van Seters, J forthcoming. The Pentateuch as Torah and history book, in defense of Gerhard von Rad, in the collected papers of Das Alte Testament und die Kultur der Moderne: Symposium anlässlich des 100. Geburtstags Gerhard von Rad (1901-1971) 18-21 October 2001. Heidelberg.

Vervenne, M \& Lust, J (eds) 1997. Deuteronomy and Deuteronomic literature. Festschrift C HW Brekelmans. Leuven: Peeters. 